\title{
Co-momentum and Stock Market Returns
}

\author{
Kailin Zeng, Ebenezer Fiifi Emire Atta Mills* \\ Department of Finance \\ Jiangxi University of Science and Technology \\ Ganzhou Academy of Financial Research (GAFR) \\ Ganzhou, China \\ attamills@jxust.edu.cn
}

\author{
Xiuzhi Zhang \\ School of Economics and Management \\ Jiangxi University of Science and Technology \\ Ganzhou Academy of Financial Research (GAFR) \\ Ganzhou, China
}

\author{
Shaolong Zeng \\ Economics and Management School \\ Hangzhou Normal University \\ Hangzhou, China
}

\begin{abstract}
As a proxy for valuable information related to momentum trading, Co-momentum variable is created based on average correlations for daily stock returns between consecutive trading days within a given period. This paper finds a negative relationship between Co-momentum and future market excess return from the US data, and the Co-momentum variable provides new and valuable information in addition to a large set of popular return predictors including average correlation, investor sentiment and price-to-dividend ratio. Furthermore, the success of Co-momentum does not depend on the forecast horizon and is robust to a variety of predictive tests.
\end{abstract}

Keywords-Co-momentum; Return forecasting; Cross-sectional correlations

\section{INTRODUCTION}

Studies have been focusing on the contrarian strategy e.g., Jegadeesh [1], and Subrahmanyam [2] and momentum strategy e.g., Jegadeesh and Titman [3][4] and implication of the strategies on cross-sectional stock returns. In addition to the cross-sectional return predictability, Mosskowitz, Ooi, and Pedersen [5] also find a phenomenon of time-series momentum for indexes. A significant difference between this paper and those previous studies is that this paper exclusively studies the average cross-sectional correlations of stock returns for a large sample of exchange-traded firms (hereafter referred to as Co-momentum) and its implication on predicting excess return of the stock market index, rather than the traditional momentum score and its implication on crosssectional return predictability.

Empirical results in this paper show that monthly and quarterly Co-momentum variables based on US data can significantly and negatively predict the corresponding stock market returns. Furthermore, the predictive power of Comomentum is not subsumed by other popular return predictors such as average correlation proposed by Pollet and Wilson [6], cay suggested by Lettau and Ludvigson [7], the price-dividend ratio proposed by Ang and Bekaert [8], and others. The goodness of fit (R2) in a monthly (quarterly) predictive regression with all these variables actually increases substantially from around 5\% (14\%) to 6\% (18\%) when Comomentum is added.

Through a set of robustness tests, I further show that the success of Co-momentum does not depend on the forecast horizon. In standard predictive regressions, but also in out-ofsample tests such as those suggested by Welch and Goyal [9] it significantly forecasts both quarterly and monthly market returns. The Co-momentum is also found capable of predicting portfolios sorted by size, book-to-market, operating profit and investment ratio. This evidence implies that the success of Comomentum is not only a phenomenon due to effects of certain firm characteristics.

\section{EMPIRICAL APPROACH}

To construct the Co-momentum variable, I consider the daily stock returns of the 500 largest firms in US from 1963 to 2013. Only the larger firms are considered here to eliminate the stock return auto-correlation due to non-synchronous trading, because the stock returns of smaller firms are with a high tendency to be affected by non-synchronous trading (Chordia and Swaminathan [10]). For each pair of two consecutive days $\mathrm{t}$ and day $\mathrm{t}-1$ in a given month or quarter, I calculate the cross-section correlation for the stock returns of the 500 largest firms traded in the US stock market. Then the( Co-momentum variable is computed as the simple average of the cross-section correlation within the month or quarter, i.e.,

$$
\mathrm{CoM}_{\mathrm{t}}=\Sigma_{\mathrm{d}} \mathrm{CSC}_{\mathrm{d}} /\left(\mathrm{N}_{\mathrm{t}}-1\right)
$$

Where $\mathrm{CSC}_{\mathrm{d}}$ represents the cross-sectional correlation for the daily stock returns of the 500 largest firms in US between day $d$ and $d-1$ in the given month (quarter). $N_{t}$ is the number of days within a given month or quarter, and $\mathrm{CoM}_{t}$ in (1) is the corresponding Co-momentum variable for month or quarter $t$.

Fig. 1 and Fig. 2 present the time-series of Co-momentum for monthly and quarterly frequency, respectively. The Comomentum is volatile and generally moving around zero. It is 
worth noting that the Co-momentum is almost always above zero for the periods from 1970 to 1975 and for the periods from 1980 to 1987 , signaling investors' preferences on a trend following trading in those periods.

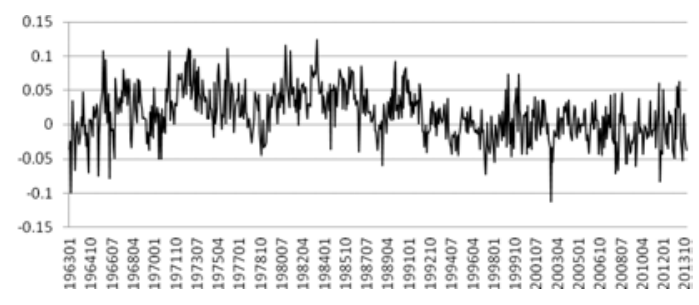

Fig. 1. Co-momentum in monthly frequency.

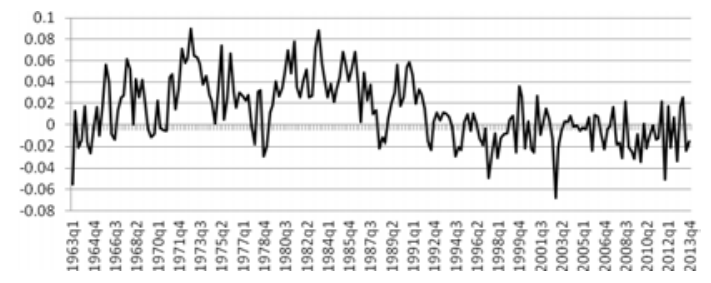

Fig. 2. Co-momentum in quarterly frequency.

\section{EMPIRICAL RESULTS}

\section{A. Summary Statistics}

Table I reports the descriptive statistics of $\mathrm{CSC}_{\mathrm{d}}$ in (1), i.e., the cross-sectional correlation of daily stock returns for the 500 largest exchange-traded US firms in every two consecutive days from 1963 to 2013 . Additionally, I report the descriptive statistics of Co-momentum for monthly and quarterly analysis. The descriptive statistics here includes the number of observations, the mean, standard deviation, skewness, maximum value, $90 \%$ quantile, $10 \%$ quantile and the minimum value.

Table I shows that the daily cross-sectional correlation $\mathrm{CSC}_{\mathrm{d}}$ has a mean close to 0 , but it is very volatile. It has standard deviation of 0.127 , about 10 times of the mean. This implies that investors are both momentum and contrarian traders in a rather short horizon. The daily cross-section correlation variable has a skewness of -0.348 , which means it sometimes take very negative values leading to a negative skewness. Finally, Table I also shows that the values of crosssection correlation mostly fall into a narrow interval between 0.15 and 0.16 , but also with some outliers such as a maximum value of 0.638 and a minimum value of -0.879 .

As monthly or quarterly average of the cross-sectional correlation, the Co-momentum variable is much less volatile, with a mean of $0.014(0.013)$ and a standard deviation of $0.037(0.030)$ for the monthly (quarterly) frequency. One striking difference from the daily cross-sectional correlation variable is that the Co-momentum variable is positively skewed rather than negatively skewed. This evidence implies that the very negative values of the cross-sectional correlation are not likely to be gathered, but spread across different periods, e.g., months or quarters. Additionally, the Co- momentum falls in a narrower interval than the cross-sectional correlation. For a monthly analysis, Co-momentum falls between -0.113 and 0.0124 , while it falls between -0.068 and 0.090 for a quarterly analysis. Using a lower frequency makes the effect of average even larger, resulting in a reduction in the extreme values of the Co-momentum.

TABLE I. SUMMARY STATISTICS OF CROSS-SECTIONAL CORRELATION AND CO-MOMENTUM

\begin{tabular}{|l|l|l|l|}
\hline & \multicolumn{1}{|c|}{ CSCd } & \multicolumn{1}{c|}{$\begin{array}{c}\text { CoM } \\
\text { (monthly) }\end{array}$} & $\begin{array}{c}\text { CoM } \\
\text { (quarterly) }\end{array}$ \\
\hline $\begin{array}{l}\text { No. of } \\
\text { Observations }\end{array}$ & 12837 & 612 & 204 \\
\hline Mean & 0.011 & 0.014 & 0.013 \\
\hline $\begin{array}{l}\text { Standard } \\
\text { deviation }\end{array}$ & 0.127 & 0.037 & 0.030 \\
\hline Skewness & -0.348 & 0.080 & 0.227 \\
\hline Max & 0.638 & 0.124 & 0.090 \\
\hline $90 \%$ Quantile & 0.160 & 0.062 & 0.055 \\
\hline $10 \%$ Quantile & -0.143 & -0.033 & -0.022 \\
\hline Min & -0.879 & -0.113 & -0.068 \\
\hline
\end{tabular}

\section{B. Predicting the Market Excess Return (In-sample)}

The main empirical analysis of this paper is the prediction of the excess return on the aggregate stock market. I first do this in the classical way in-sample, i.e., the predictive regression is performed only once for the complete sample. More precisely, the market excess return for the period from $t$ to $\mathrm{t}+1$ is regressed on a set of variables, including Comomentum, observable at time t.

To see if Co-momentum actually represents a new dimension, I also include variables, which have been shown previously to predict future market excess returns. For instance, predictor capturing the idiosyncratic risk clustering $\mathrm{Sig}_{4}$ proposed by Schlag and Zeng [11], average variance AV, average correlation $\mathrm{AC}$ and average covariance $\mathrm{ACV}$ suggested by Pollet and Wilson [6], return dispersion RD by Maio [12], short-term reversal Strev by Jegadeesh [1], momentum UMD by Jegadeesh and Titman [4], and the investor sentiment suggested by Baker and Wurgler [13], as well as other standard predictors such as the lagged market excess return $R_{m}-R_{f}$ suggested by Hong, Torous and Valkanov [14], cay from Lettau and Ludvigson [7], the risk-free rate $R_{f}$ and the log price-dividend ratio pd based on the findings in Ang and Bekaert [8].

Table II shows the results of in-sample analysis for both monthly and quarterly frequency. Co-momentum exhibits strongly significant coefficients, be it as the only regressor in simple regressions or together with a large set of controls in multiple regressions. Taking multiple regressions without Comomentum variable as the benchmark, I find furthermore that Co-momentum adds substantial explanatory power when added to the regression, since the $\mathrm{R}^{2}$ goes up from $5.07 \%$ to $5.92 \%$ for the monthly regressions and from $13.82 \%$ to $17.96 \%$ for the quarterly regressions. It's worthy to note that the coefficient of Co-momentum takes a negative sign. This implies that the more significant the trend of cross return momentum is, the more likely the price of the market index will fall. An explanation for this evidence is that when 
speculative trading predominates over hedging, an overvaluation of the market index is likely the outcome.

TABLE II. PREDicting THE MARKET EXCESS RetURn (IN-SAMPLE)

\begin{tabular}{|c|c|c|c|c|c|c|}
\hline & \multicolumn{3}{|c|}{ Monthly Regressions } & \multicolumn{3}{|c|}{ Quarterly Regressions } \\
\hline & simple & $\begin{array}{c}\text { Multiple } \\
\text { (excluding CoM) }\end{array}$ & Multiple & simple & $\begin{array}{c}\text { Multiple } \\
\text { (excluding CoM) }\end{array}$ & Multiple \\
\hline Constant & $\begin{array}{l}0.70 * * * \\
(3.37)\end{array}$ & $\begin{array}{l}7.2 * * * \\
(2.16)\end{array}$ & $\begin{array}{l}8.22 * * * \\
(2.52)\end{array}$ & $\begin{array}{l}2.41^{* * *} \\
(4.01)\end{array}$ & $\begin{array}{l}13.99 \\
(1.21)\end{array}$ & $\begin{array}{l}21.13^{*} \\
(1.92)\end{array}$ \\
\hline $\mathrm{CoM}$ & $\begin{array}{l}-15.34 * * * \\
(-3.41)\end{array}$ & & $\begin{array}{l}-14.96^{* * *} \\
(-2.76)\end{array}$ & $\begin{array}{l}-69.78 * * * \\
(-4.13)\end{array}$ & & $\begin{array}{l}-78.9 * * * \\
(-3.45)\end{array}$ \\
\hline Sig4 & & $\begin{array}{l}245.33 * * * \\
(4.07)\end{array}$ & $\begin{array}{l}234.91 * * * \\
(3.88)\end{array}$ & & $\begin{array}{l}215.98^{* * * *} \\
(10.82)\end{array}$ & $\begin{array}{l}197.09^{* * *} \\
(9.82)\end{array}$ \\
\hline $\mathrm{AV}$ & & $\begin{array}{l}1.61 \\
(1.23)\end{array}$ & $\begin{array}{l}1.39 \\
(1.06)\end{array}$ & & $\begin{array}{l}0.71 \\
(0.62)\end{array}$ & $\begin{array}{l}0.28 \\
(0.24)\end{array}$ \\
\hline $\mathrm{AC}$ & & $\begin{array}{l}7.80^{* * * *} \\
(3.44)\end{array}$ & $\begin{array}{l}6.88^{* * *} \\
(2.91)\end{array}$ & & $\begin{array}{l}26.73 * * * \\
(4.04)\end{array}$ & $\begin{array}{l}20.97 * * * \\
(3.04)\end{array}$ \\
\hline $\mathrm{ACV}$ & & $\begin{array}{l}-4.72^{*} \\
(-1.74) \\
\end{array}$ & $\begin{array}{l}-4.32 \\
(-1.57) \\
\end{array}$ & & $\begin{array}{l}-2.66 \\
(-1.13)\end{array}$ & $\begin{array}{l}-1.72 \\
(-0.69)\end{array}$ \\
\hline $\mathrm{RD}$ & & $\begin{array}{l}-0.04 \\
(-0.13)\end{array}$ & $\begin{array}{l}0.05 \\
(0.15)\end{array}$ & & $\begin{array}{l}0.92 \\
(0.92)\end{array}$ & $\begin{array}{l}1.38 \\
(1.37)\end{array}$ \\
\hline $\mathrm{Rm}-\mathrm{Rf}$ & & $\begin{array}{l}4.30 \\
(1.12)\end{array}$ & $\begin{array}{l}5.52 \\
(1.45)\end{array}$ & & $\begin{array}{l}4.98 \\
(0.71)\end{array}$ & $\begin{array}{l}9.16 \\
(1.29)\end{array}$ \\
\hline UMD & & $\begin{array}{l}-0.95 \\
(-0.23)\end{array}$ & $\begin{array}{l}-0.45 \\
(-0.11)\end{array}$ & & $\begin{array}{l}-2.13 \\
(-0.25)\end{array}$ & $\begin{array}{l}1.32 \\
(0.16)\end{array}$ \\
\hline Strev & & $\begin{array}{l}0.64 \\
(0.12)\end{array}$ & $\begin{array}{l}-2.04 \\
(-0.38) \\
\end{array}$ & & $\begin{array}{l}4.45 \\
(0.60) \\
\end{array}$ & $\begin{array}{l}-1.77 \\
(-0.26) \\
\end{array}$ \\
\hline Cay & & $\begin{array}{l}15.23 * \\
(1.92)\end{array}$ & $\begin{array}{l}14.64 \\
(1.85) \\
\end{array}$ & & $\begin{array}{l}70.25 * * * \\
(2.60)\end{array}$ & $\begin{array}{l}65.38 * * * \\
(2.52)\end{array}$ \\
\hline $\mathrm{Pd}$ & & $\begin{array}{l}-2.02 * * \\
(-2.36)\end{array}$ & $\begin{array}{l}-2.25 * * * \\
(-2.71)\end{array}$ & & $\begin{array}{l}-5.00^{*} \\
(-1.67)\end{array}$ & $\begin{array}{l}-6.64 * * \\
(-2.36)\end{array}$ \\
\hline $\mathrm{Rf}$ & & $\begin{array}{l}-31.83^{* * *} \\
(-3.45)\end{array}$ & $\begin{array}{l}-28.35^{* * *} \\
(-3.16)\end{array}$ & & $\begin{array}{l}-73.53^{* *} \\
(-2.21)\end{array}$ & $\begin{array}{l}-52.25^{*} \\
(-1.79)\end{array}$ \\
\hline Sentiment & & $\begin{array}{l}1.64 \\
(0.07) \\
\end{array}$ & $\begin{array}{l}-3.63 \\
(-0.16) \\
\end{array}$ & & $\begin{array}{l}-1.47 \\
(-0.02) \\
\end{array}$ & $\begin{array}{l}-32.33 \\
(-0.48) \\
\end{array}$ \\
\hline R2(\%) & 1.41 & 5.07 & 5.92 & 5.45 & 13.82 & 17.96 \\
\hline
\end{tabular}

\section{Predicting the Market Excess Return over Long Horizons}

To see if the predictive power of Co-momentum is limited to short-horizon forecasts over the next month or quarter, I perform the tests over longer, multi-month and multi-quarter horizons. The controlling variables that are employed for the in-sample analysis in the previous section are also included here. All predictive regressions are performed in sample. The coefficients of Co-momentum are annualized, and the tstatistics are adjusted for the presence of overlapping observations by following the method proposed by Hodrick [15].
The results are presented in Table III, with Panel A and Panel B for monthly and quarterly frequency, respectively. I find that Co-momentum has strong forecasting power for market excess returns for long horizons up to 24 months for monthly analysis or 8 quarters for quarterly analysis, even when a large set of standard controls are included in the regression. The annualized coefficients decrease somewhat in absolute value with the forecasting horizon, but the t-statistics indicate significance at the $1 \%$-level throughout.

TABLE III. PREDICTING THE MARKET EXCESS RETURN OVER LONG HORIZON

\begin{tabular}{|c|c|c|c|c|c|c|c|c|}
\hline \multicolumn{9}{|c|}{ Panel A: Forecasting Horizon for Monthly Regressions (Months) } \\
\hline & 3 & 6 & 9 & 12 & 15 & 18 & 21 & 24 \\
\hline $\mathrm{CoM}$ & $\begin{array}{l}-1.28 * * * \\
(-2.86)\end{array}$ & $\begin{array}{l}-1.11 * * * \\
(-3.25)\end{array}$ & $\begin{array}{l}-1.10 * * * \\
(-3.25)\end{array}$ & $\begin{array}{l}-1.03 * * * * \\
(-3.68)\end{array}$ & $\begin{array}{l}-1.11^{* * * *} \\
(-4.79)\end{array}$ & $\begin{array}{l}-1.03 * * * \\
(-4.65)\end{array}$ & $\begin{array}{l}-0.96^{* * *} \\
(-4.48)\end{array}$ & $\begin{array}{l}-0.81^{* * * *} \\
(-4.25)\end{array}$ \\
\hline $\mathrm{R}^{2}(\%)$ & 15.73 & 24.90 & 27.91 & 30.91 & 36.43 & 41.76 & 47.26 & 52.77 \\
\hline \multicolumn{9}{|c|}{ Panel B: Forecasting Horizon for quarterly Regressions (Quarters) } \\
\hline & 1 & 2 & 3 & 4 & 5 & 6 & 7 & 8 \\
\hline $\mathrm{CoM}$ & $\begin{array}{l}-3.20^{* * *} \\
(-3.44)\end{array}$ & $\begin{array}{l}-2.01 * * * \\
(-2.79)\end{array}$ & $\begin{array}{l}-1.74 * * * \\
(-2.78)\end{array}$ & $\begin{array}{l}-1.74 * * * \\
(-3.44)\end{array}$ & $\begin{array}{l}-1.88^{* * * *} \\
(-4.38)\end{array}$ & $\begin{array}{l}-1.85^{* * * *} \\
(-4.95)\end{array}$ & $\begin{array}{l}-1.65^{* * *} \\
(-4.63)\end{array}$ & $\begin{array}{l}-1.28^{* * * *} \\
(-3.90)\end{array}$ \\
\hline $\mathrm{R}^{2}(\%)$ & 17.96 & 24.19 & 28.10 & 33.06 & 37.65 & 44.91 & 50.76 & 53.45 \\
\hline
\end{tabular}

\section{Predicting the Market Excess Return (Out-of-sample)}

The in-sample exercise provides strong evidence in favor of the predictive power of Co-momentum. The real test, however, is whether a variable can also predict out of sample.
This is not a trivial challenge, as documented by Welch and Goyal [9], who test a battery of variables as predictors for the equity premium and find at best weak evidence for predictability. In the out-of-sample analysis, I follow the approach suggested in that paper and consider variables such 
as R2, RMSE, MSE-F and ENC to test for predictability of market excess returns. A bootstrap method is used to compute the probability that the forecasting quality of the given predictor is inferior to that of the mean of the available sample. The number of bootstrapping experiments is 1000 .

Table IV presents the results for the monthly (upper panel) and the quarterly (bottom panel) analysis. Co-momentum generates strong out-of-sample predictability for both quarterly and monthly market excess returns. The bootstrapped quality statistics are all positive and statistically significant at the 5\% level. As such, Co-momentum is a very powerful predictor in both in-sample and out-of-sample analyses, unlike the standard predictors that usually perform very well in-sample but fail the out-of-sample tests (Welch and Goyal [9]).

TABLE IV. PRedicting The MARKet Excess Return (OUT-OFSAMPLE)

\begin{tabular}{|l|l|l|l|}
\hline \multicolumn{5}{|c|}{ First forecast is made after observing K share of the sample } \\
\hline \multicolumn{4}{|c|}{ Panel A: Monthly Forecasting } \\
\hline \multicolumn{5}{|c|}{$\mathrm{K}=1 / 4$} & $\mathrm{~K}=1 / 3$ \\
\hline $\mathrm{R} 2$ & $0.01^{* * *}$ & $0.01^{* *}$ & $0.01^{* *}$ \\
\hline$\triangle \mathrm{RMSE}$ & $0.45^{* * *}$ & $0.24^{* *}$ & $0.22^{* *}$ \\
\hline $\mathrm{MSE}-\mathrm{F}$ & $4.36^{* * *}$ & $2.20^{* *}$ & $1.79^{* *}$ \\
\hline $\mathrm{ENC}$ & $0.02^{* * *}$ & $0.01^{* * *}$ & $0.01^{* * *}$ \\
\hline \multicolumn{5}{|c|}{ Panel B: Quarterly Forecasting } \\
\hline $\mathrm{R} 2$ & $0.03^{* * *}$ & $0.02^{* *}$ & $0.03^{* *}$ \\
\hline$\triangle \mathrm{RMSE}$ & $1.32^{* * *}$ & $1.16^{* *}$ & $1.04^{* *}$ \\
\hline $\mathrm{MSE}-\mathrm{F}$ & $4.03^{* * *}$ & $3.24 * *$ & $2.63^{* *}$ \\
\hline $\mathrm{ENC}$ & $0.05^{* * *}$ & $0.05^{* * *}$ & $0.05^{* * *}$ \\
\hline
\end{tabular}

\section{E. Predicting the Stock Portfolios}

In this section, I find that Co-momentum variable can also predict a set of quintile portfolios sorted by size, book-tomarket ratio, operating profit, and investment ratio. The returns of the portfolios are obtained directly from French's online data library. The motivation of the portfolio test is that return predictability for the market excess return might be driven only by a group of stocks with certain firm characteristics. I find that this is not true based on the analytical results in Table $\mathrm{V}$.

Table $\mathrm{V}$ reports the coefficients and t-statistics (within the parentheses) for the regressions of 20 portfolios sorted by size, book-to-market ratio, operating profit, and investment ratio on the Co-momentum. The coefficients for most of the portfolios (except two monthly portfolios that are large in book-tomarket ratio) are statistically significant for $1 \%$ level. This evidence implies that success of the Co-momentum for the market excess return is not driven by stocks with certain wellknown firm characteristics.

\section{CONCLUSION}

The paper creates a Co-momentum variable based on simple average of cross-sectional correlation for daily stocks returns of large firms in US between two consecutive days in a given period. The Co-momentum is devoted to proxy the momentum or contrarian related trading for the financial market, rather than a single stock. Empirical findings in this paper strongly support that the Co-momentum is negatively related to the future market excess return in US. And this evidence applies over long horizon, and is robust for both insample and out-of-sample forecasting tests. Furthermore, I find that this negative relationship between Co-momentum and future market excess return is not only driven by a group of stocks with certain firm characteristics. Overwhelming in speculative trading might be the explanation to the negative relationship between Co-momentum and future market excess return.

TABLE V. PREDICTING THE PORTFOLIO RETURNS

\begin{tabular}{|c|c|c|c|c|c|}
\hline \multicolumn{6}{|c|}{ Panel A: Monthly Regressions } \\
\hline $\begin{array}{l}\text { Portfolio } \\
\text { sorted by }\end{array}$ & Q1 & 2 & 3 & 4 & Q5 \\
\hline Size & $\begin{array}{l}-16.89^{* * *} \\
(-2.44)\end{array}$ & $\begin{array}{l}-16.46^{* * * *} \\
(-2.65)\end{array}$ & $\begin{array}{l}-15.51 * * * \\
(-2.81)\end{array}$ & $\begin{array}{l}-15.46^{* * * *} \\
(-3.13)\end{array}$ & $\begin{array}{l}- \\
11.22 \\
* * * \\
(- \\
2.58)\end{array}$ \\
\hline $\begin{array}{l}\text { Book-to- } \\
\text { Market } \\
\text { ratio }\end{array}$ & $\begin{array}{l}-15.16^{* * *} \\
(-3.16)\end{array}$ & $\begin{array}{l}-12.67 * * * \\
(-2.74)\end{array}$ & $\begin{array}{l}-10.81 * * \\
(-2.42)\end{array}$ & $\begin{array}{l}-7.51 \\
(-1.51)\end{array}$ & $\begin{array}{l}-8.74 \\
(- \\
1.61) \\
\end{array}$ \\
\hline $\begin{array}{l}\text { Operating } \\
\text { Profit }\end{array}$ & $\begin{array}{l}-13.99 * * \\
(-2.41)\end{array}$ & $\begin{array}{l}-11.05 * * \\
(-2.30)\end{array}$ & $\begin{array}{l}-8.83^{*} \\
(-1.88)\end{array}$ & $\begin{array}{l}-11.77 * * * \\
(-2.55)\end{array}$ & $\begin{array}{l}- \\
13.46 \\
* * * \\
(- \\
2.85)\end{array}$ \\
\hline $\begin{array}{l}\text { Investmen } \\
\text { t Ratio }\end{array}$ & $\begin{array}{l}-13.59 * * * \\
(-2.65)\end{array}$ & $\begin{array}{l}-9.14 * * \\
(-2.15)\end{array}$ & $\begin{array}{l}-10.22 * * \\
(-2.27)\end{array}$ & $\begin{array}{l}-12.84 * * * \\
(-2.67)\end{array}$ & $\begin{array}{l}17.39 \\
* * * \\
(- \\
3.07)\end{array}$ \\
\hline \multicolumn{6}{|c|}{ Panel B: Quarterly Regressions } \\
\hline $\begin{array}{l}\text { Portfolio } \\
\text { sorted by }\end{array}$ & Q1 & 2 & 3 & 4 & Q5 \\
\hline Size & $\begin{array}{l}-85.38 * * * \\
(-3.25)\end{array}$ & $\begin{array}{l}-77.97 * * * \\
(-3.24)\end{array}$ & $\begin{array}{l}-71.61 * * * \\
(-3.28)\end{array}$ & $\begin{array}{l}-69.56^{* * * *} \\
(-3.45)\end{array}$ & $\begin{array}{l}- \\
50.11 \\
* * * \\
(- \\
3.10)\end{array}$ \\
\hline $\begin{array}{l}\text { Book-to- } \\
\text { Market } \\
\text { ratio }\end{array}$ & $\begin{array}{l}-62.06^{* * * *} \\
(-3.33)\end{array}$ & $\begin{array}{l}-58.21 * * * \\
(-3.46)\end{array}$ & $\begin{array}{l}-55.78 * * * \\
(-3.36)\end{array}$ & $\begin{array}{l}-45.07 * * * \\
(-2.71)\end{array}$ & $\begin{array}{l}- \\
61.21 \\
* * * \\
(- \\
3.05)\end{array}$ \\
\hline $\begin{array}{l}\text { Operating } \\
\text { Profit }\end{array}$ & $\begin{array}{l}-67.68 * * * \\
(-3.40)\end{array}$ & $\begin{array}{l}-57.50 * * * \\
(-3.12)\end{array}$ & $\begin{array}{l}-48.23 * * * \\
(-2.96)\end{array}$ & $\begin{array}{l}-55.12 * * * \\
(-3.12)\end{array}$ & $\begin{array}{l}55.05 \\
* * * \\
(- \\
2.95)\end{array}$ \\
\hline $\begin{array}{l}\text { Investmen } \\
\text { t Ratio }\end{array}$ & $\begin{array}{l}-66.14 * * * \\
(-3.44)\end{array}$ & $\begin{array}{l}-46.84 * * * \\
(-2.89)\end{array}$ & $\begin{array}{l}-46.89 * * * \\
(-2.80)\end{array}$ & $\begin{array}{l}-57.69 * * * \\
(-3.15)\end{array}$ & $\begin{array}{l}68.03 \\
* * * \\
(- \\
3.25)\end{array}$ \\
\hline
\end{tabular}

\section{ACKNOWLEDGMENT}

The authors gratefully acknowledge research support from the Humanities and Social Sciences Foundation of the Ministry of Education of China (Study on the Process Matching between China's Capital Account Liberalization and the "Belt and Road". Grant No. 18YJCGJW001). Any errors are our own.

\section{REFERENCES}

[1] N. Jegadeesh, "Evidence of predictable behavior of security returns," Journal of Finance, vol. 45, pp. 881-898, 1990. 
[2] A. Subrahmanyam, "Distinguishing Between Rationales for ShortHorizon Predictability of Stock Returns," The Financial Review, vol. 40, pp. 11-35, 2005.

[3] N.Jegadeesh and S. Titman, "Returns to buying winners and selling losers: Implications for stock market efficiency," Journal of Finance, vol 48, pp. 65-91, 1993

[4] N. Jegadeesh and S. Titman, "Profitability of momentum strategies: An evaluation of alternative explanations," Journal of Finance, vol. 56, pp. 699-720, 2001.

[5] T.J. Moskowitz, Y.H. Ooi, and L.P. Pedersen, "Time series momentum," Journal of Financial Economics, vol. 104, pp. 228-250, 2012.

[6] M.J. Pollet and M. Wilson, "Average correlation and stock market returns," Journal of Financial Economics, vol. 96, pp. 364-380, 2010.

[7] M. Lettau and S. Ludvigson, "Consumption, aggregate wealth, and expected stock returns," Journal of Finance, vol. 56, pp. 815-849, 2001.

[8] A. Ang and G. Bekaert, "Stock return predictability: Is it there?" Review of Financial Studies, vol. 20, pp. 651-707, 2006
[9] I. Welch and A. Goyal, "A comprehensive look at the empirical performance of equity premium prediction," Review of Financial Studies, vol. 21, pp. 1455-1508, 2008.

[10] T. Chordia and B. Swaminathan, "Trading volume and CrossAutocorrelations in Stock Returns," Journal of Finance, vol. 55, pp. 913936, 2000.

[11] C. Schlag and K. Zeng, "Idiosyncratic clustering and stock market returns," unpublished.

[12] P. Maio, "Cross-sectional return dispersion and the equity premium," Journal of Financial Markets, vol. 29, pp. 87-109, 2016.

[13] M. Baker and J. Wurgler, "Investor Sentiment and the Cross-Section of Stock Returns," Journal of Finance, vol. 61(4), pp. 1645-1680, 2006.

[14] H. Hong, W. Torous, and R. Valkanov, "Do industries lead stock markets?" Journal of Financial Economics, vol 83, 2007, pp. 367-396.

[15] R.J. Hodrick, "Dividend yields and expected stock returns: Alternative procedures for inference and measurement," Review of Financial Studies, vol. 5, pp. 357-386, 1992. 